message but in a more entertaining style, perhaps because his serious but flowing story was laced with irrelevant cartoons and adverts including fast cars, whisky, cameras, jewellery and beautiful women, but more probably because he linked history with current field-work in different parts of the States.

IMAGE
UNAVAILABLE
FOR
COPYRIGHT
REASONS

James Ussher, Bishop of Armagh - calculated the date of creation as $4004 \mathrm{BC}$.

So here I am, vaguely dissatisfied with a perfectly adequate book simply because of a feeling of déja vu. How can one be constructive? More might have been made of Archbishop Ussher (1581-1656) and his method of calculating the date of creation $(4004 \mathrm{BC})$ and such subsequent events as the grounding of the Ark on Mount Ararat on May 5, 1491 BC (a Wednesday!). His chronology was incorporated in the most widely read book of the day - the King James VI bible - and so had an undue influence in Protestant countries. Many of the subsequent philosophical and scientific investigations described in the Abyss of Time were carried out in the shadow of Ussher's precise chronology. Astronomical calculations and coral clocks are not referred to but they show that the Earth is now rotating more slowly than it did during the Devonian when a year was all of 399 days. Above all, data from meteorites and Moon rocks reveal fascinating events earlier than any now preserved on Earth and provide independent factual evidence of the great antiquity of our Solar System and planet. They could have been the subject of a separate chapter.

And what of the future? The abyss is just as much in front of us as behind. The Earth is steadily losing its heat. As it continues to cool the lithospheric plates will thicken and stop moving: eventually there will be no more volcanic activity and no more earthquakes, but the land will continue to be eroded seawards, there to remain because uplift will no longer occur. The rock cycle will finally have come to an end: but there is perhaps consolation in the fact that the Sun will continue to shine until in another 5,000 million years it too becomes cold. And after that? But Albritton does not indulge in such fantasies.

G.Y. Craig is Professor of Geology at the University of Edinburgh.

\title{
Trap for the unwary
}

\author{
William H. McNeill
}

The Fates of Nations: A Biological Theory of History. By Paul Colinvaux. Pp.383. ISBN 0-671-25204-6. (Simon and Schuster: 1980.) \$12.95 US only.

FOR the intellectual wanderer, impatient with the myopia of specialization, there are great risks in invading an unfamiliar turf. Jealous experts lie in wait for the newcomer to display his ignorance of their discipline by some slip of tongue or pen, and the complications of the new subject may not conform readily to the insights the newcomer brings from some other discipline.

This, unfortunately, is the case with Paul Colinvaux's book, The Fates of Nations. Colinvaux is an ecologist whose speciality is Ice Age Alaska and the land bridge which once allowed animals and plants to migrate from Asia to America across what is now the Bering Strait. For general readers, however, his best-known work is a summation of recent ecological niche theory which goes by the catchy title Why Big Fierce Animals are Rare (recently issued in paperback by Penguin). As an historian, who, like Colinvaux, has found it irresistible to wander across recognized disciplinary boundaries, I found this essay instructive and persuasive. But now when he takes on my own field of expertise, the human past, and seeks to illumine it by bringing ecological niche theory to bear, I find Colinvaux's ideas inadequate and his information radically defective.

As he engagingly explains at the end of the book in a "Note on Sources and Substance", he began to think about a "formal theory of history" in 1971, relying on the history "which is the common knowledge of Christendom", i.e. on what he remembered from his school days in England. This he reinforced by reading Toynbee's "overview of history's facts", and by consulting a few experts on battles - Livy, Tacitus, Arrian - as well as more modern writers like Liddell Hart and J. F. C. Fuller. He found the barrister Edward Creasy's Fifteen Decisive Battles of the World, first published in 1854, especially useful, while Field Marshal Montgomery's A History of Warfare supplied him with "the clearest insight into what gave victory in many a crucial battle"'. Thus, as Colinvaux tells us himself, his method of mastering history was studiously to disregard what professional historians have been doing since World War I to modify the patriotic and political history so ably caricatured in 1066 and All That.

With 1066 and All That plus school-boy Latin as his guide, and Toynbee as guarantor of "facts", what does an intrepid ecologist discover in the human past? The answer is a rhythm of rise and fall, predictable in the light of ecological niche theory. It may be summarized as follows. Initially, history starts when a group of human beings develops a new technique that allows them to enlarge the ecological niches in which they live. This leads to a rise in population, for human beings have always pursued a breeding strategy - the large young gambit - that requires each breeding couple to raise as many children as they think they can afford. This strategy, Colinvaux assures us, has never altered, though he does not assert that it is instinctive.

Once enlarged niche spaces start to fill up as population increases, the prospering community faces a crisis. Since growing numbers with no increase in resources will force them to accept narrower niches again, they must look abroad to find the means to sustain their heightened expectations. Trade, colonization and aggressive war, aimed at taking land away from those in possession, are the alternatives such a population faces, and this is what history is all about. Successful communities expand and create empires; but sooner or later, expansion ceases. Colinvaux is completely silent on what stops expansion. On his principles I can see no reason for the process he sketches not to continue indefinitely, until the most successful aggressor has created an empire of the Earth. But the "common knowledge of Christendom" makes clear that a limit was set somehow, and Colinvaux shows his deference to facts by stopping the expansion of the Roman Empire at the Rhine and Danube - though, as I say, he gives no reason for this interruption of a process which he has declared to be both predictable and inevitable.

Once territorial expansion stops, the continued growth of population requires narrowed niches; and narrowed niches will be accepted only reluctantly by the population concerned. This means an oppressive government - a police state in fact, in which the rich, clinging to their broad niches, impose their power on the poor by dint of "regimentation, bureaucracy, class, rationing and caste", (p. 64). Such a regime is vulnerable from without, and eventually barbarian invaders, technologically abreast of the latest methods of civilized warfare, will succeed in destroying the oppressive regime by cutting off food supplies to the cities. The newcomers institute a barbarian pattern of life in which local consumers depend on local food production. This sharply reduces the total number of inhabitants, since the urban masses, congregated under the regime of civilization into vast cities, are unable to maintain the breeding strategy that had hitherto led to an ever-mounting population. They simply die off, leaving a sparsely settled countryside to start the cycle of civilization over again. 
Echoes of Toynbee's cycle are obvious, though the emotive tone that Colinvaux's ecological vision imposes is utterly at odds with Toynbee's humanistic and religious values. There are, too, some serious anomalies in this thesis, for the modern cycle of civilization does not conform closely to the classical Mediterranean pattern.

An even greater anomaly is introduced in Colinvaux's final chapter "The Shape of Things to Come". After exploring the implications of this theory, which predicts that growing populations will launch aggressive war in order to maintain enlarged ecological niches, he apparently reverses himself by saying that it "may well be that our breeding strategy will yield even smaller families for the moderately affluent than they have now" (p. 313), since one may hope that "new roles for women will hold down the population and let us all live in freedom"' (p. 314). So because "we breed in human and controllable ways" and can understand what is happening to us, we "need fear neither our future nor our fate"' (p. 321). But if human breeding strategy is alterable now, why not in the past? And if one group of people in this twentieth century does decide to have fewer children in order to maintain broader niches, what prevents others from breeding incontinently and filling in the space occupied by the rich and continent, not by conquest, but by the less spectacular method of in-migration?

This sort of population shift is occurring before our eyes, as Gastarbeiter in Germany, illegal aliens in the USA and Asians in England attest. It occurred in distant ages as well. The replacement of Sumerian speakers by Semites in ancient Mesopotamia in the 3rd millennium BC and the bitter jibes of the Roman poet Juvenal against the Greeklings whom he saw taking over favoured places in Roman society, are only two examples of the past importance of peaceful migration. Indeed, all great imperial cities of times past have been polyethnic in their population. They were places where diverse peoples congregated and died off due to the intensified disease exposure involved in urban living before the days of modern sanitation. Colinvaux seems unaware of this traditional population dynamic, well attested though it is for early modern Europe when statistical records begin to become available to historians. Indeed he is ignorant of all historical demography, though for a theory that puts such emphasis on population growth as the fundamental disturber of history he surely ought to have guarded himself against the sort of reproach I make of his procedures by at least consulting a few elementary textbooks on historical demography. If he had done so, he would have discovered that historians are agreed that the population of the Roman Empire declined sharply in the second and third centuries AD, recovered partially in the fourth century and then plummeted again in the fifth. Colinvaux's picture of an ever-rising population pressing harder and harder on available niches therefore runs counter to all modern historical scholarship.

As a matter of fact, Colinvaux is aware of some of the signs of depopulation that manifested themselves in late Roman times. But he dismisses empty fields and unoccupied border regions where Roman authorities settled barbarian tribesmen from beyond the frontier as a predictable consequence of population growth! The argument is sufficiently bizarre to deserve quotation in full:

From the time of troubles onward the population shifts within the state. There is a drift from the land as peasants are displaced in the interests of increased production. This happened in ancient Greece and Rome no less than in the time of the enclosures in Tudor England, or in modern industrial states. The process can be seen in the development of every civilization. Feeding great numbers of people is more easily done if they are brought together in dense settlements; running the agriculture needed to supply these dense settlements is more efficient in the larger agricultural units of agribusiness. And the "drift from the land" is a predictable consequence of a dense population growing denser [pp. 83-84].

To test this hypothesis one might look for some indication of the growth of cities while fields emptied out. Roman cities from the 3 rd century onward conveniently provided such an index by erecting ring walls necessitated by the declining level of public security in the empire. By modern standards these enclosures were tiny indeed, and diminish with each rebuilding. Where is the massive, ever-growing urban population Colinvaux's theory requires? Even on a purely theoretical level, and without the vulgar appeal to mere data, one would suppose that before propounding his ridiculous hypothesis Colinvaux might have asked himself how it could be more efficient to carry food from the fields to distant urban consumers (in ox carts presumably), and how "agribusiness" could plough and reap in the absence of modern machinery, and without numerous labourers on the spot to do the work. The fact is that human populations rise and fall in complicated and only partially understood ways, and in response to a far wider range of shifting conditions than Colinvaux's system admits.

My judgment of The Fate of Nations is that in venturing beyond the boundaries of his discipline Colinvaux has come a cropper. This is a pity, for surely there are useful things historians might learn from ecologists, and an ecologist who took the pains to acquaint himself with historical literature might indeed be in a position to shed new light on familiar historical conundrums.

William H. McNeill is Professor of History at the University of Chicago, and auther of The Human Condition (Princeton University Press, 1980).

\section{THE EARTH'S PROBLEM CLIMATES}

\section{Second Edition \\ by Glenn T Trewartha}

In this new and extensively revised edition, the author takes into account new information and climactic data that

have become available since the

original edition appeared in 1961.

Trewartha offers an inventory of the more important of the earth's problem climates, brief and concise descriptions of their characteristics, and suggested explanations for at least some of them:

in so doing, he draws together the

results of numerous definitive studies in dynamic climatology.

Wisconsin, May 1981, 352 pp, illus, cloth $£ 13.50$

\section{VOLCANOES OF THE EARTH}

\section{by Fred M Bullard}

a first-rate and up-to-date account of one of the world's most intriguing phenomena." - Explorers Journal

Texas, 597 pp, 24 colour plates, 183 b\&w illus, now in paperback at $E 12.00$

AMERICAN UNIVERSITY

PUBLISHERS GROUP LTD

1 Gower Street

London WC1

Telephone (01) 5803994

Circle No.41 on Reader Enquiry Card.

\section{SCIENCE AT THE WHITE HOUSE}

\author{
A Political Liability
}

EDWARD J. BURGER, JR.
foreword by DON K. PRICE

From the day the first atomic bomb was dropped, scientists gained a new image in the public's eye. In the succeeding decades, there seemed to be no limit to what technology could accomplish, from military weapons to moon walks. Science at the White House looks at what happened when America's new experts were called in to serve as advisers to the president.

As cases in point, Burger assesses the government's efforts at planning for key issues that emerged during his tenure as a science adviser: issues concerning national health care, environmental regulation, and population and family planning, among others.

$208 \mathrm{pp}, £ 9.00$.

THE JOHNS HOPKINS UNIVERSITY PRESS

Ely House, 37 Dover Street, London W.1. 